\title{
Characterization of disulfide exchange between DsbA and HtrA proteins from Escherichia coli
}

\author{
Joanna Skórko-Glonek ${ }^{\bowtie}$ Anna Sobiecka-Szkatuła and Barbara Lipińska \\ Department of Biochemistry, University of Gdańsk, Gdańsk, Poland; \\ 凶e-mail: glonek@biotech.univ.gda.pl
}

Received: 20 March, 2006; revised: 30 August, 2006; accepted: 16 September, 2006

available on-line: 01 October, 2006

\begin{abstract}
DsbA is the major oxidase responsible for generation of disulfide bonds in proteins of $E$. coli envelope. In the present work we provided the first detailed characterization of disulfide exchange between DsbA and its natural substrate, HtrA protease. We demonstrated that HtrA oxidation relies on DsbA, both in vivo and in vitro. We followed the disulfide exchange between these proteins spectrofluorimetrically and found that DsbA oxidizes HtrA with a 1:1 stoichiometry. The calculated second-order apparent rate constant $\left(k_{\text {app }}\right)$ of this reaction was $3.3 \times 10^{4} \pm 0.6 \times 10^{4}$ $\mathrm{M}^{-1} \mathrm{~s}^{-1}$. This value was significantly higher than the values obtained for nonfunctional disulfide exchanges between DsbA and DsbC or DsbD and it was comparable to the $k_{\text {app }}$ values calculated for in vitro oxidation of certain non-natural DsbA substrates of eukaryotic origin.
\end{abstract}

Keywords: HtrA protease, DsbA oxidoreductase, disulfide exchange, stoichiometry of HtrA-DsbA interaction, kinetics of HtrA oxidation

\section{INTRODUCTION}

Disulfide bonds are widely found in many exported proteins and contribute to the folding and stability of these proteins. In eukaryotic cells, oxidative folding of disulfide proteins takes place in the endoplasmic reticulum, whereas in prokaryotes this process occurs in the periplasmic space. In the bacterium Escherichia coli the disulfides are generated by the DsbA-DsbB system. DsbA is the primary catalyst of disulfide bond formation and is responsible for oxidation of newly translocated polypeptides. DsbA is a member of thioredoxin family and functions by transferring a disulfide bond from its active site to the substrate protein, undergoing reduction in the process. DsbA is active in the oxidized form; therefore the electrons from reduced DsbA are passed to the second component of the system, the inner membrane protein DsbB, which transfers them to the respiratory chain component, a quinone. Oxidation of substrate proteins by DsbA occurs rapidly and nonspecifically and may result in the formation of incorrect disulfide bonds which will need subsequent isomerization, the function catalyzed by another oxidoreductase system, DsbC-DsbD. The components of the two systems do not interact at physiological conditions and work independently (reviewed in Fabianek et al., 2000; Nakamoto \& Bardwell, 2004).

Disulfides typically function to stabilize the tertiary structure of a protein and are often crucial for the protein to achieve the native, active conformation. Proteins deprived of their proper disulfide bonds frequently lack their enzymatic activity, are unstable or tend to aggregate (Missiakas \& Raina, 1997; Spiess et al., 1999). For example, alkaline phosphatase is a periplasmic protein that contains two disulfide bonds necessary for correct folding. One of these bonds is required for the protein stability; the second is indispensable for the enzymatic activity (Sone et al., 1997). Another protein whose stability is affected by the lack of its disulfide bond is HtrA protein form E. coli. HtrA is a periplasmic serine protease attached to the inner membrane (SkórkoGlonek et al., 1997). It functions predominantly in the removal of irreversibly damaged or abnormal proteins from cellular envelope (Clausen et al., 2002) and its cellular content is elevated in various stress conditions, including heat shock, oxidative stress and presence of reducing agents (Skórko-Glonek et al., 2003). HtrA contains in its N-terminal region 
two cysteine residues (C57 and C69) which at physiological conditions are involved in disulfide bridge formation. In cells grown in the presence of reducing agents HtrA exists in the reduced form and undergoes autodegradation (Skórko-Glonek et al., 2003). The autocleavage takes place after C69 or after Q82 of the mature protein and occurs only in a reducing environment (Skórko-Glonek et al., 1995; 2003). The cleaved protein retains its activity, however, its certain biochemical properties are affected. In particular, the cleaved HtrA loses its quaternary structure (monomerizes) and shows lower affinity towards membrane phospholipids (Skórko-Glonek et al., 2003). Thus, the disulfide bond in the N-terminal region of HtrA plays an important stabilizing role and oxidation of C57 and C69 residues seems to be an important step in HtrA folding. It is assumed that generation of disulfide bonds within most envelope proteins occurs in a DsbA-dependent reaction; however, no direct evidence of disulfide exchange between HtrA and DsbA has been provided so far. In this work we prove that HtrA is indeed a substrate for DsbA. Although the interactions between E. coli Dsb proteins have been studied extensively, little data is available describing the kinetics of disulfide exchange between Dsb proteins and their natural substrates in the process of postranslocational folding. In our study we present a detailed characterization of the HtrA-DsbA interaction, including measurements of the apparent rate constant of HtrA oxidation.

\section{MATERIALS AND METHODS}

Strains and growth conditions. E. coli strains and plasmids used are listed in Table 1. Strains KB5,8-9 were constructed by bacteriophage P1 transduction of appropriate mutations from BL20 or JCB817, or JCB819 to the wild type MG1655 E. coli strain. The strains were grown at $30^{\circ} \mathrm{C}$ in $\mathrm{M} 63$ medium supplemented with $0.1 \%$ amino acids (except for cysteine and methionine) and appropriate antibiotic. Growth of bacteria was monitored by measuring the increase in $\mathrm{OD}_{595}$.

Determination of redox states. The in vivo redox state of HtrA was assayed by trapping the free thiols by iodoacetamide (IAA) according to a method adapted from Jacob et al. (1999) and Kishigami et al. (1995). Portions of $0.7 \mathrm{ml}$ of each culture were withdrawn and mixed with $0.2 \mathrm{ml}$ of $0.45 \mathrm{M}$ IAA in $100 \mathrm{mM}$ Tris, $10 \mathrm{mM}$ EDTA, $\mathrm{pH}=9.2$. The samples were incubated at $37^{\circ} \mathrm{C}$ for $2 \mathrm{~min}$ and the reaction was stopped with trichloroacetic acid (TCA) (10\% final concentration). Prior to the addition of TCA lysozyme was added to a final concentration of $0.2 \mathrm{mg} / \mathrm{ml}$ to improve the efficiency of precipitation.
All samples were incubated overnight at $-20^{\circ} \mathrm{C}$, and then were centrifuged for $30 \mathrm{~min}$ at $4^{\circ} \mathrm{C}$ and 20000 $\times g$. The pellets were resuspended in a nonreducing Laemmli lysis buffer supplemented with $20 \mathrm{mM}$ IAA.

Protein purification. The HtrA S210A protein was purified from K38(pGP1-2)(pJS14) overproducing strain basically as described previously (SkórkoGlonek et al., 1995). The only modifications were the lack of dithiothreitol in the buffer for opening the cells and of $\beta$-mercaptoethanol in all buffers.

DsbA protein was a generous gift from Professor R. Glockshuber (Institut für Molekularbiologie und Biophysik, ETH Hoenggerberg, Switzerland).

Purity of the proteins was checked on SDS/ PAGE and was at least 95\%.

Electrophoresis of proteins and Western blotting. Proteins were analyzed by SDS/PAGE as described by Laemmli (1970). Western blotting was performed as previously described (Oberfelder, 1993).

Determination of protein concentration. HtrA concentration was estimated by staining with Amido Black and spectrophotometric measurement as described before (Lipińska et al., 1990). DsbA concentration was determined using its absorption coefficient at $280 \mathrm{~nm}$ according to Gill and von Hippel (1989) with $\varepsilon_{280}=23250 \mathrm{M}^{-1} \mathrm{~cm}^{-1}$.

Fluorescence spectroscopy. The experiments of titration of reduced HtrA with oxidized DsbA were performed according to Grauschopf et al. (2003), at $25^{\circ} \mathrm{C}$ in $1 \mathrm{ml}$ quartz cuvettes (Hellma) with stirring. Reduced HtrAS210A $(1 \mu \mathrm{M})$ in a volume of $1 \mathrm{ml}$ was titrated stepwise with $5 \mu \mathrm{l}$ aliquots of a solution of oxidized DsbA $(40 \mu \mathrm{M})$. The excitation wavelength was $280 \mathrm{~nm}$. Band widths were $1 \mathrm{~nm}$ for excitation beam and $2 \mathrm{~nm}$ for the emission beam. The fluorescence at $330 \mathrm{~nm}$ was recorded after 10 min of incubation and corrected for the volume increase.

The kinetics of the oxidation of HtrA $(1 \mu \mathrm{M})$ by DsbA $(1 \mu \mathrm{M})$ in $20 \mathrm{mM}$ Hepes, $\mathrm{pH}=7.0,0.5 \mathrm{mM}$ EDTA were monitored at $25^{\circ} \mathrm{C}$ in $200 \mu \mathrm{l}$ quartz cuvettes (light path $3 \mathrm{~mm}$, Hellma), by the change in fluorescence at $330 \mathrm{~nm}$. Data were evaluated according to second order kinetics.

\section{RESULTS AND DISCUSSION}

The redox state of HtrA in $d s b A$ or $d s b B$ mutant strains

HtrA has in its N-terminal part two cysteines and in bacteria grown in physiological conditions HtrA is present mainly in the oxidized form. How- 
ever, in cultures grown in the presence of reducing agents HtrA exists predominantly in the reduced form and its synthesis is elevated (Skórko-Glonek et al., 2003). The most probable enzyme responsible for oxidation of the cysteines within HtrA is DsbA and we expected that in the $d s b A$ mutant strain HtrA would be present in the reduced state. To prove this assumption we checked the redox state of HtrA expressed in $d s b A$ and also $d s b B$ background by comparing the electrophoretic mobility of HtrA in cell extracts derived from $d s b A$ or $d s b B$ mutant strains. As controls we used purified preparation of oxidized HtrAS210A (a proteolytically inactive mutant) and cell extract containing the cysteineless HtrAS210AC57SC69S ( $\triangle$-CysHtrAS210A), representing reduced HtrA. We decided to use the proteolytically inactive HtrA mutants because reduced wild type HtrA undergoes autodegradation which makes the HtrA protein pattern more complicated (SkórkoGlonek et al., 2003). As shown in Fig. 1, lane 1, $\Delta$ CysHtrAS210A had a decreased electrophoretic mobility when compared to the oxidized HtrA control (lane 2). HtrA expressed in the $d s b A$ or $d s b B$ mutant strain migrated at the same position as $\triangle$-CysHtrAS210A, indicating that it was present in the reduced state (lanes 3,4). The similar effects on the redox state of HtrA observed for both mutant strains are not surprising. In the absence of DsbB, DsbA protein should remain in a reduced state and should not be active as an oxidase. Thus, it could be concluded that $\mathrm{DsbA}$ is responsible for the in vivo oxidation of HtrA. The existence of physical interactions between DsbA and HtrA, and of a possible disulfide exchange, was further supported by our observation that certain amount of DsbA copurified with HtrAS210A during Ni-affinity chromatography (not shown). Furthermore, DsbA was not present in $\Delta$ CysHtrAS210A preparations, indicating that forma-

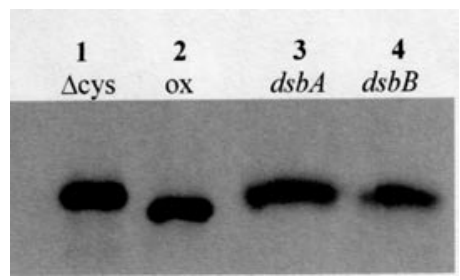

Figure 1. HtrA is a substrate for DsbA oxidoreductase in vivo.

E. coli MG1655 htrA(pJS20) bacteria, expressing cysteineless HtrAS210AC57SC69S ( $\triangle$-Cys HtrAS210A) and MG1655 $h t r A d s b A(\mathrm{pJS17}), \mathrm{MG} 1655$ htrAdsbB(pJS17), both expressing HtrAS210A, were grown as described in Materials and Methods. Protein samples obtained from equal numbers of cells were resolved by nonreducing SDS/PAGE $(10 \%$ gel) and subjected to Western analysis using anti-HtrA antibodies. The lanes show $\Delta$-Cys HtrAS210A (lane 1), purified oxidized HtrA S210A (lane 2) and HtrAS210A expressed in the $d s b A$ mutant cells (lane 3) or in the $d s b B$ mutant cells (lane 4). tion of the HtrA-DsbA mixed disulfides could be responsible for the observed interactions (not shown).

\section{In vitro analysis of HtrA oxidation by DsbA}

To more directly demonstrate that HtrA is oxidized by DsbA we performed in vitro experiments using purified HtrA and DsbA proteins. We titrated reduced HtrA with increasing quantities of oxidized DsbA and monitored the redox reaction spectrofluorimetrically. This method is based on the spectral properties of both proteins: DsbA exhibits a 3 -fold increase in tryptophan fluorescence upon reduction (Wunderlich \& Glockshuber, 1993), whereas HtrA basically remains fluorescently silent upon oxidation. Since HtrA has no tryptophan residues, its intrinsic fluorescence is very low, therefore changes in the signal due to HtrA in the conditions of the experiment were assumed as negligible. The titration profile (Fig. 2, graph "a") was characterized by a sharp kink at a DsbA/HtrA ratio of 1:1. The linear slopes before and after the kink correspond to the specific fluorescence of reduced and oxidized DsbA, respectively. The kink became more visible when the fluorescence signal values obtained for increasing concentrations of oxidized DsbA (graph " $\mathrm{c}$ ") were subtracted from titration values. As could be seen in Fig. 2, graph " $b$ ", no further increase of fluorescence occurred at DsbA/HtrA ratios greater than 1:1, which means that DsbA oxidizes HtrA with a $1: 1$ stoichiometry. The presence of the sharp kink indicates that DsbA is significantly more oxidizing than $\mathrm{HtrA}$; in the case of proteins whose redox potential values are similar the titration curve has a different profile (Graushopf et al., 2003).

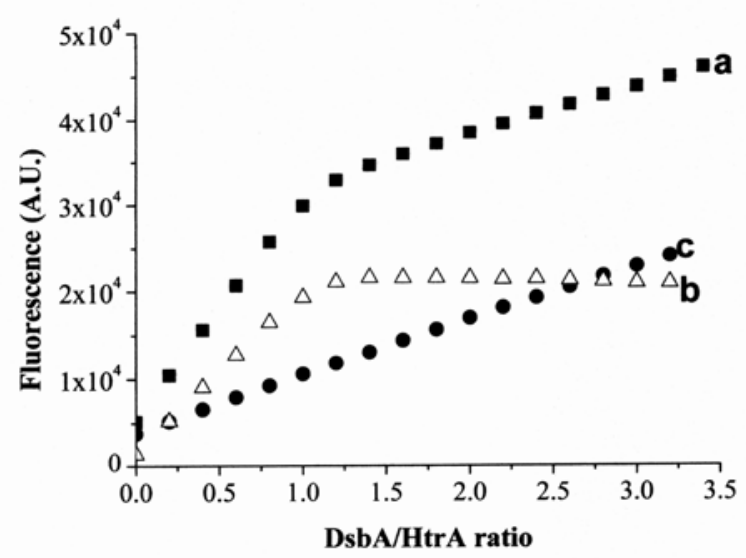

Figure 2. HtrA interacts with DsbA with 1:1 stoichiometry.

Reduced HtrA S210A (1 $\mu \mathrm{M})$ was titrated with oxidized wild type DsbA in a buffer containing $20 \mathrm{mM}$ Hepes, $\mathrm{pH}=7.0$ and $0.1 \mathrm{mM}$ EDTA. The fluorescence at $330 \mathrm{~nm}$ was plotted against the DsbA/HtrA ratio (a). Graph " $b$ " represents values obtained by subtraction of fluorescence signals due to the buffer and the oxidized DsbA (c) from experimental values presented on graph " $a$ ". 
Table 1. Bacterial strains and plasmids.

\begin{tabular}{|c|c|c|}
\hline \multicolumn{2}{|c|}{ Relevant characteristics } & Reference or source \\
\hline \multicolumn{3}{|l|}{ Strains } \\
\hline BL20 & W3110 htrA63 galE sup ${ }^{+}$ & Lipińska et al. (1989) \\
\hline MG1655 & wt E. coli & Our collection \\
\hline JCB817 & JCB $816 d s b A^{-}$ & J. C. A. Bardwell \\
\hline JCB819 & JCB $816 d s b B^{-}$ & J. C. A. Bardwell \\
\hline K38(pGP1-2) & $\operatorname{HfrC}(\lambda)$, T7 polymerase, $\operatorname{Kan}^{R}$ & Tabor \& Richardson (1985); Russel \& Model (1984) \\
\hline KB5 & MG1655htrA & Our collection \\
\hline KB8 & MG1655 htrA dsbA & Our collection \\
\hline KB9 & MG1655 htrA dsbB & Our collection \\
\hline \multicolumn{3}{|l|}{ Plasmids: } \\
\hline pT7-5 & T7 expression vector & Tabor \& Richardson (1985) \\
\hline pJS14 & pT7-5 carrying $h$ trAS210A (Ser210 $\rightarrow$ Ala substitution) & Skórko-Glonek et al. (1995) \\
\hline pTA3 & $\begin{array}{l}\text { pQE60 derivative carrying } h \operatorname{tr} A \text { gene with substitu- } \\
\text { tions Cys } 57 \rightarrow \text { Ser, Cys } 69 \rightarrow \text { Ser }\end{array}$ & M. Ehrmann \\
\hline pJS17 & pQE60 derivative carrying $h t r A S 210 A$ gene & Skórko-Glonek et al. (2003) \\
\hline pJS20 & same as pTA3 but with Ser $210 \rightarrow$ Ala substitution & Skórko-Glonek et al. (2003) \\
\hline
\end{tabular}

Kinetic analysis of DsbA-HtrA disulfide exchange

We measured the rate constant of the disulfide exchange reaction between DsbA and HtrA by following the changes in tryptophan fluorescence. As shown in Fig. 3, the reaction was quite rapid. The calculated second-order apparent rate constant $\left(k_{\text {app }}\right)$ was $3.3 \times 10^{4} \pm 0.6 \times 10^{4} \mathrm{M}^{-1} \mathrm{~s}^{-1}$. Since no data concerning the kinetics of redox exchange of DsbA and its natural substrates in the posttranslocational folding is available we compared the obtained $k_{\text {app }}$ value with the $k_{\text {app }}$ values calculated for in vitro disulfide exchange reactions between DsbA and other Dsb proteins, and between DsbA and non-natural substrates of eukaryotic origin. The reaction between $\mathrm{DsbA}$ and $\mathrm{DsbB}$ is a functional reaction occurring at physiological conditions, whereas the reactions

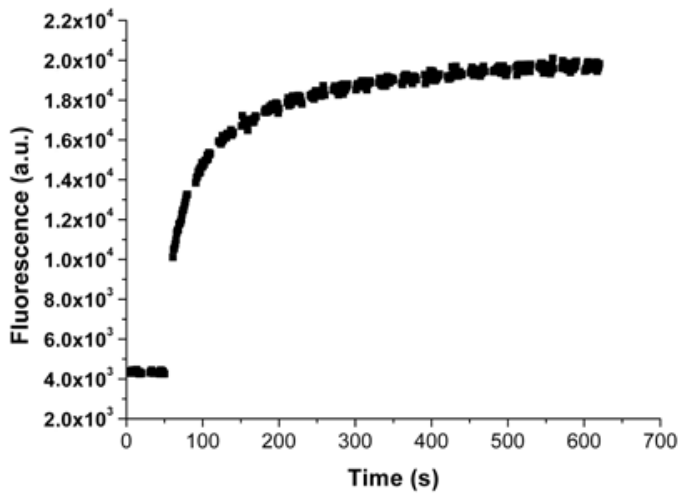

Figure 3. DsbA/ HtrA disulfide exchange.

The figure shows an example of the measurement of DsbA reduction by HtrA. First, the baseline signal due to HtrA $(2 \mu \mathrm{M})$ and buffer was recorded (the first $40 \mathrm{~s})$. Then, an equal volume of $2 \mu \mathrm{M}$ DsbA solution was added and the change in fluorescence intensity at $330 \mathrm{~nm}$ was immediately recorded. between DsbA and DsbC or DsbD (members of an independent oxidoreductase system) are regarded as nonfunctional. The oxidation of DsbA by DsbB is an extremely rapid process with a $k_{\text {app }}$ value above $10^{6} \mathrm{M}^{-1} \mathrm{~s}^{-1}$. The nonfunctional disulfide exchange reactions are $10^{6}-10^{4}$ fold slower than the functional electron transfer (for example: $k_{\text {app }}=0.3 \mathrm{M}^{-1} \mathrm{~s}^{-1}$ for DsbA/C-terminal domain of DsbD; $4 \mathrm{M}^{-1} \mathrm{~s}^{-1}$ for $\mathrm{DsbA} / \mathrm{DsbC})$. The value obtained for the DsbA/HtrA disulfide exchange is significantly higher than those of the nonfunctional reactions and is comparable to the $k_{\text {app }}$ calculated for the disulfide exchange between DsbA and bovine pancreatic trypsin inhibitor $\left(10^{5} \mathrm{M}^{-1} \mathrm{~s}^{-1}\right)$ (Zapun \& Creighton, 1994) or mammalian metallothionein $\left(4.4 \times 10^{5} \mathrm{M}^{-1} \mathrm{~s}^{-1}\right)$ (Hu et al., 1999). Although it is lower than the $k_{\text {app }}$ of the reaction between DsbA and DsbB, we must bear in mind that in the living cell DsbA oxidizes the newly translocated polypeptide lacking its tertiary and quaternary structure and such reaction may occur much faster. It has been shown that DsbA binds unfolded polypeptides preferentially and, for example, DsbA reacts 10-25 times faster with unfolded reduced hirudin than with one treated with dithiothreitol only (Wunderlich et al., 1993). This could be relevant to the mechanism of de novo oxidative folding of proteins in the E. coli envelope. To our knowledge this is the first detailed study of the stoichiometry and kinetics of the oxidation process performed by DsbA on a natural periplasmic substrate, implicated in the folding of proteins in the periplasmic space in E. coli.

\section{CONCLUSIONS}

In the present work we provided the first direct evidence that HtrA protein is a substrate for 
DsbA oxidoreductase. This statement is based on the following findings:

1. In cells deprived of a functional DsbA/DsbB system HtrA existed in the reduced state.

2. HtrA was oxidized by DsbA in vitro in a 1:1 stoichiometry. The apparent rate constant of this reaction was comparable to the known $k_{\text {app }}$ values calculated for DsbA/substrate disulfide exchange.

\section{Acknowledgements}

We are grateful to R. Glockshuber for his kindness, advice and stimulating discussion and for giving the possibility to perform the experiments on HtrA-DsbA interactions; A. Rozhkova and P. Frei for assistance in performing these experiments; J.C.A. Bardwell for the generous gift of the $d s b$-deficient strains; M. Ehrmann for the gift of pTA3 plasmid and for his helpful advice throughout the work; J. Potrykus for constructing the KB strains.

This work was supported by grant No. 1074/ P04/2004/26 from the Ministry of Education and Science.

\section{REFRENCES}

Churchward G, Belin D, Nagamine Y (1984) Gene 31: 165171.

Clausen T, Southan C, Ehrmann M (2002) Mol Cell 10: 443455.

Fabianek RA, Hennecke H, Thony-Meyer L (2000) FEMS Microbiol Rev 24: 303-316.

Gill SC, Von Hippel PH (1989) Anal Biochem 182: 319-326.

Grauschopf U, Fritz A, Glockshuber R (2003) EMBO J 22: 3503-3513.
Henneke J, Sebel P, Glockshuber R (1999) J Mol Biol 286: 1197-1215.

Hu HY, Cheng HQ, Li Q, Zou YS, Xu GJ (1999) J Protein Chem 18: 665-670.

Jakob U, Muse W, Eser M, Bardwell JCA (1999) Cell 96: 341-352.

Kishigami S, Akiyama Y, Ito K (1995) FEBS Lett 364: 5558.

Krojer T, Garrido-Franco M, Huber R, Ehrmann M, Clausen T (2002) Nature 416: 455-459.

Laemmli UK (1970) Nature 227: 680-685.

Lipińska B, Żylicz M, Georgopoulos C (1990) J Bacteriol 172: 1791-1797.

Missiakas D, Raina S (1997) J Bacteriol 179: 2465-2471.

Nakamoto H, Bardwell JCA (2004) Biochim Biophys Acta 1694: 111-119.

Oberfelder R (1993) In Methods in Nonradioactive Detection (Howard GC ed), pp 83-85, Appleton \& Lange, Norwalk, Connecticut.

Rozhkova A, Stirnimann CU, Frei P, Graushopf U, Brunisholtz R, Grutter MG, Capitani G, Glockshuber R (2004) EMBO J 23: 1709-1719.

Russel M, Model P (1984) J Bacteriol 159: 1034-1039.

Skórko-Glonek J, Wawrzynów A, Krzewski K, Kurpierz K, Lipińska B (1995) Gene 163: 47-52.

Skórko-Glonek J, Lipińska B, Krzewski K, Zolese G, Bertoli E, Tanfani F (1997) J Biol Chem 272: 8974-8982.

Skórko-Glonek J, Żurawa D, Tanfani F, Scire A, Wawrzynów A, Narkiewicz J, Bertoli E, Lipińska B (2003) Biochim Biophys Acta 1649: 171-182.

Sone M, Kishigami S, Yoshihisa T, Ito K (1997) J Biol Chem 272: 6174-6178.

Spiess C, Beil A, Ehrmann M (1999) Cell 97: 339-347.

Tabor S, Richardson CC (1985) Proc Natl Acad Sci USA 82: 1074-1078.

Wunderlich M, Otto A, Seckler R, Glockshuber R (1993) Biochemistry 32: 12251-6.

Wunderlich M, Glockhuber R (1993) Protein Sci 2: 717-726.

Zapun A, Creighton TE (1994) Biochemistry 33: 5202-5211. 